\title{
Pengembangan Bioflok dan Kolam Budidaya Ikan sebagai Wisata Edukasi di Desa Tulungrejo Kecamatan Glenmore Kabupaten Banyuwangi
}

\author{
Development of Biofloc and Fish Culture Pond as Educational Tourism in Tulungrejo Village, \\ Glenmore District, Banyuwangi Regency
}

\author{
Himma Silviana ${ }^{1}$, Ika Yuniwati ${ }^{2 *}$, Zulis Erwanto ${ }^{3}$, D. Triasih ${ }^{4}$ \\ ${ }^{1}$ Jurusan Manajemen Bisnis Pariwisata, Politeknik Negeri Banyuwangi \\ ${ }^{2}$ Jurusan Teknik Mesin, Politeknik Negeri Banyuwangi \\ ${ }^{3}$ Jurusan Teknik Sipil, Politeknik Negeri Banyuwangi \\ ${ }^{4}$ Jurusan Teknologi Pengolahan Hasil Ternak, Politeknik Negeri Banyuwangi \\ *ika@poliwangi.ac.id
}

\begin{abstract}
ABSTRAK
KKP merilis data tingkat konsumsi ikan diproyeksikan bisa mencapai 50 kilogram per kapita. Angka tersebut, menjelaskan bahwa suplai pangan untuk perikanan akan sangat bergantung pada perikanan budidaya. Sedangkan peran ikan sebagai benteng ketahanan pangan nasional, hingga kini dinilai masih belum maksimal. Berdasarkan profil Desa Tulungrejo dan tingkat kemajuan Desa Tulungrejo, Kecamatan Glenmore berjalan lambat, karena rendahnya tingkat pendidikan, minimnya keterampilan serta sarana dan prasarana. Keadaan ini menyebabkan masyarakat tidak mampu menggali potensi yang ada dengan maksimal dan tidak mampu menciptakan peluang. Kondisi di Desa Tulungrejo sebenarnya memiliki banyak kekayaan alam yang lebih dan sumber airnya melimpah. Oleh karena itu melalui pengembangan dan penerapan teknologi bioflok diharapkan Desa Tulungrejo dapat menjadi salah satu sentra penghasil perikanan air tawar dan menjadi lokasi percontohan bagi kawasan lainnya. Selain itu, diharapkan dapat mewujudkan masyarakat yang mandiri secara ekonomi dan sosial. Tujuan dari kegiatan Program Hibah Desa Binaan disini yaitu dapat meningkatkan perekonomian masyarakat dan pendapatan daerah dari hasil budidaya akuakultur, serta dapat mengefisiensi pakan ikan dari teknologi bioflok sehingga diharapkan dapat meningkatkan produktivitas perikanan air tawar. Bahkan program ini terus berkesinambungan sampai membentuk masyarakat desa mampu secara mandiri dan produktif untuk budidaya perikanan darat dan mampu membentuk kelembagaan koperasi untuk memutar keuntungan dari hasil panen. Pengembangan teknologi bioflok yang memungkinkan peningkatan produktivitas tinggi, ramah lingkungan efisien dalam penggunaan lahan dan sumber daya air. Hasil luaran lainnya perikanan air tawar yang dikembangkan mampu menjadi wisata edukasi bagi masyarakat yang ingin mengetahui proses budidaya ikan.
\end{abstract}

Kata kunci — akuakultur, bioflok, tilapia, wisata edukasi

\begin{abstract}
The KKP released data on the level of fish consumption that is projected to reach 50 kilograms per capita. This figure explains that the food supply for fisheries will depend heavily on aquaculture. Meanwhile, the role of fish as a bulwark of national food security is still considered not optimal. Based on the profile of Tulungrejo Village and the level of progress of Tulungrejo Village, Glenmore District, the progress is slow, due to the low level of education, lack of skills and facilities and infrastructure. This situation causes the community to be unable to explore the existing potential to the maximum and unable to create opportunities. The condition in Tulungrejo Village actually has more natural wealth and abundant water sources. Therefore, through the development and application of biofloc technology, it is hoped that Tulungrejo Village can become one of the centers for producing freshwater fisheries and become a pilot location for other areas. In addition, it is expected to create a society that is economically and socially independent. The purpose of the Assisted Village Grant Program activities here is to increase the community's economy and local income from aquaculture cultivation, and to be able to streamline fish feed from biofloc technology so that it is expected to increase the productivity of freshwater fisheries. In fact, this program continues to be sustainable until forming village communities capable of independently and productively for inland aquaculture and able to form cooperative institutions to rotate profits from harvests. Development of biofloc technology that enables high productivity, environmentally friendly and efficient use of land and water resources. Other outcomes of freshwater fisheries that have been developed are able to become educational tours for people who want to know the process of fish farming.
\end{abstract}

Keywords - aquaculture, biofloc, tilapia, educational 


\section{Pendahuluan}

Di Indonesia, KKP merilis data bahwa tingkat konsumsi ikan diproyeksikan bisa mencapai 50 kilogram per kapita per orang. Angka tersebut, menjelaskan bahwa suplai pangan untuk perikanan akan sangat bergantung pada perikanan budidaya. Diprediksi 60 persen dari total kebutuhan ikan nasional akan dipasok dari perikanan budidaya. Jadi, tantangannya adalah, bagaimana mencukupi kebutuhan pangan masyarakat dunia, khususnya Indonesia di tengah permasalahan penurunan daya dukung lingkungan dan perubahan iklim secara global. Peran ikan sebagai benteng ketahanan pangan nasional, hingga kini dinilai masih belum maksimal.

Berdasarkan profil Desa Tulungrejo (2017), tingkat kemajuan Desa Tulungrejo, Kecamatan Glenmore berjalan lambat, masih banyak ketertinggalan di berbagai bidang. Melihat tingginya angka kemiskinan dan tingginya tingkat pengangguran di usia produktif. Kondisi ini tidak terlepas dari beberapa faktor penunjang yang masih dirasakan sangat kurang. Terjadinya kemiskinan dan pengangguran di usia produktif di Desa Tulungrejo umumnya disebabkan oleh rendahnya tingkat pendidikan, minimnya keterampilan, dan sarana dan prasarana yang kurang layak. Keadaan ini menyebabkan masyarakat Desa Tulungrejo tidak mampu menggali potensi yang ada dengan maksimal dan tidak mampu menciptakan peluang, rendahnya daya saing masyarakat seolah memperburuk kondisi ekonomi. Padahal di Desa Tulungrejo memiliki banyak kekayaan alam yang lebih, dan sumber airnya melimpah. Khususnya dalam pengelolaan sumber air irigasi yang dimanfaatkan oleh Kelompok Ikan Sumber Mulyo dalam pengembangan akuakultur atau budidaya perikanan air darat seperti ikan Lele, ikan Nila, ikan Gurami, Ikan Mas, dan Ikan Hias Koi.

Kegiatan budidaya sendiri tidak terlepas dari pemberian pakan, namun tidak semua pakan yang diberikan dapat dimanfaatkan oleh ikan. Hal ini sesuai dengan pernyataan Purnomo (2012) [8] , yaitu hanya $25 \%$ nitrogen dari pakan yang dapat diasimilasi menjadi daging, sedangkan $75 \%$ dibuang ke lingkungan. Pakan yang terbuang ke perairan akan menjadi limbah. Salah satu langkah pengelolaan yang potensial untuk memanfaatkan limbah di perairan dan sebagai sumber pakan tambahan adalah dengan memanfaatkan bakteri yang ada di perairan yaitu dengan penerapan teknologi bioflok yang didasarkan pada manipulasi rasio $\mathrm{C} / \mathrm{N}$. Menurut Avnimelech (2009) [2] ,Teknologi bioflok mampu menyediakan pakan tambahan berprotein untuk hewan budidaya sehingga dapat meningkatkan pertumbuhan, selain itu teknologi ini juga efektif menurunkan limbah nitrogen anorganik dari sisa pakan dan kotoran. Penggunaan bakteri dalam sistem budidaya telah banyak dilakukan, baik untuk manajemen kualitas air maupun sebagai campuran pakan. Dalam teknologi bioflok, peran bakteri heterotrof sangat dominan. Pertumbuhan bakteri heterotrof dapat dirangsang dengan meningkatkan rasio $\mathrm{C} / \mathrm{N}$ dengan penambahan karbohidrat atau penurunan protein pada pakan. Material karbon ini akan mengikat nitrogen anorganik yang digunakan untuk pertumbuhan sel bakteri.

\section{Target dan Luaran}

Tingkat kesejahteraan masyarakat Desa Tulungrejo masih belum merata. Oleh karena itu melalui penerapan teknologi bioflok diharapkan Desa Tulungrejo dapat menjadi salah satu sentra penghasil perikanan air tawar melalui pengembangan akuakultur dengan pemanfaatan sumber air irigasi yang melimpah dan menjadi lokasi percontohan bagi kawasan lainnya. Selain itu, diharapkan dapat mewujudkan masyarakat yang mandiri secara ekonomi dan sosial, meningkatkan keterampilan masyarakat untuk berwirausaha dan mengolah produk hasil perikanan yang dibudidayakan, serta meningkatkan kesejahteraan melalui pembentukan Koperasi Kampung Ikan bagi kelompok pembudidaya ikan.

\section{Metodologi}

Metode pelaksanaan dalam program ini adalah membuat inovasi produk perikanan budidaya yang berkelanjutan dengan berlandaskan pada adaptasi dan motivasi perubahan iklim. Cara seperti ini, bisa dipertimbangkan karena di masa mendatang perikanan budidaya diprediksi akan menjadi 
andalan dunia untuk pemenuhan kebutuhan pangan. Pengembangan teknologi bioflok yang memungkinkan peningkatan produktivitas tinggi, ramah lingkungan efisien dalam penggunaan lahan, dan sumber daya air.

Teknologi bioflok tersebut mengadopsi bentuk rekayasa lingkungan yang mengandalkan suplai oksigen dan pemanfaatan mikroorganisme, dan secara langsung dapat meningkatkan nilai kecernaan pakan. Kelebihan dari teknologi bioflok ini, bisa mengintegrasikan diri dengan sistem hidroponik, nilai survival rate/SR hingga lebih dari 90 persen dan tanpa pergantian air, nilai Feed Conversion Ratio (FCR) mencapai 1,03. Secara terminologi biofloc berasal dari dua suku kata yaitu Bio yang berarti biologi atau hidup dan Floc yang berarti gumpalan. BIO-FLOC adalah flok atau gumpalan-gumpalan kecil yang tersusun dari sekumpulan mikroorganisme hidup yang melayang-layang di air.

\section{Pembahasan}

Adapun proses dari pengembangan biofloc ini melalui beberapa tahapan sebagai berikut.

\subsection{Survei awal}

Hasil survei awal dengan permasalahan pada kelompok mitra menunjukkan bahwa solusi yang dapat ditawarkan kepada kelompok mitra adalah dengan memanfaatkan potensi sumber daya perairan air irigasi, saluran-saluran irigasi, dan kolam buatan yang ada di sekitar warga untuk dapat dimanfaatkan sebagai tempat budidaya ikan air tawar seperti ikan nila merah yang memiliki nilai ekonomis yang cukup serta dapat digunakan sebagai wisata edukasi. Masyarakat tidak perlu mengeluarkan biaya tambahan untuk pembuatan kolam karena dapat memanfaatkan sumber daya perairan yang telah tersedia. Selain itu pemberian penyuluhan / pelatihan tentang teknologi bioflok dalam pengembangan akuakultur sehingga dapat mengefisiensi pakan ikan dan mampu meningkatkan produktivitas ikan sehingga lebih cepat panen.

Pada survei awal yang kita lakukan, kita melakukan penelitian pada kolam-kolam ikan yang ada di Sekitar rumah-rumah pemilik kolam/tambak ikan. Keadaan yang ada di Desa Tulungrejo sebagian penduduk berprofesi sebagai pembudidaya ikan nila dan lele. Di desa tulungrejo memiliki kelompok pembudidaya ikan sebanyak \pm 15 anggota dan syarat jika ingin menjadi anggota harus mempunyai kolam ikan sendiri. Sejak awal pembentukan kelompok ikan secara keseluruhan sudah mengalami 10 kali masa panen kurang lebih panen ikan lele mencapai waktu 3 bulan sekali sedangkan ikan nila mencapai waktu 6 bulan sekali. Panen dilakukan secara bergilir dari kolam satu ke kolam lainya, dari bibit setelah menjadi peranakan dipindahkan ke kolam khusus peranakan dan setelah dewasa maka ikan tersebut akan dipindah kolam dewasa dan akhirnya siap panen, kegiatan tersebut dilakukan secara berkesinambungan. 1 indukan ikan nila bisa menghasilkan kurang lebih 100 butir telur.

\subsection{Identifikasi Masalah dan Penetapan Khalayak Sasaran}

Kendalanya ada pada Dana yang digunakan untuk membeli pakan ikan. Harga pakan ikan sangat mahal dan tidak bisa di siasati, sudah mencoba pakan alternatif yaitu tumbuhan Azola dan Fermentasi tetapi masih saja keuntungan masih sangat tipis dan tidak sesuai harapan, karena tumbuhan tersebut benar membuat badan ikan menjadi besar akan tetapi bobotnya tidak sesuai dengan ukuran yang diharapkan. Khalayak sasaran pada pengabdian ini yaitu Kelompok ikan Sumbermulyo

\subsection{Penyusunan program}

Kegiatan dalam pengabdian ini meliputi Sosialisasi program kerja ke kelompok mitra; Penyuluhan teknologi bioflok dengan pemanfaatan air irigasi untuk pengembangan akuakultur sebagai wisata edukasi dan sistem koperasi; Penerapan teknologi bioflok pada kolam-kolam atau bak pembibitan ikan;

\subsection{Perumusan dan pengukuran indikator keberhasilan}

Dengan adanya program ini diharapkan dapat membantu mengatasi permasalahan yang ada dan meningkatkan perekonomian kelompok perikanan sumber mulyo melalui budidaya ikan dengan teknologi bioflok, indikator keberhasilan 
program ini $90 \%$ karna kami mengadakan pelatihan dengan menghadirkan narasumber yang ahli di bidangnya jadi keberhasilan program ini sangat besar.

\subsection{Pelaksanaan Program}

Sosialisasi kegiatan Program Hibah Bina Desa tentang rencana program kerja di kelompok mitra.

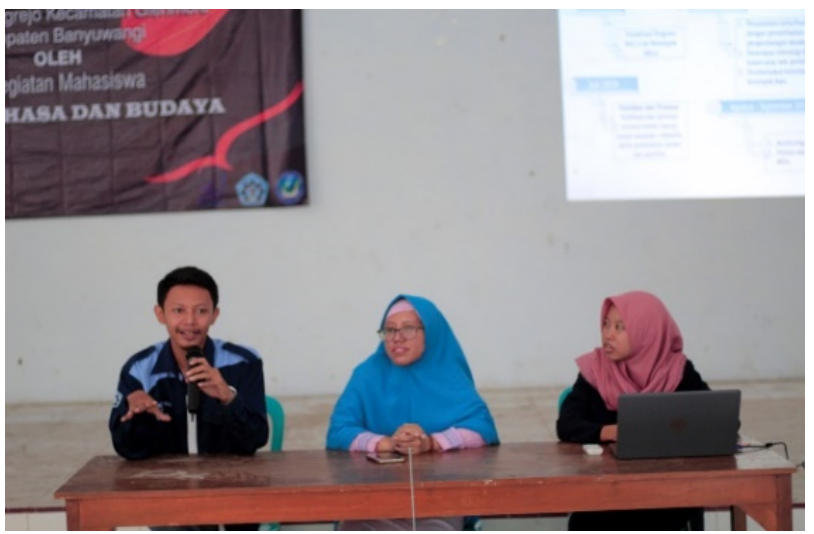

Gambar 1. Kegiatan Sosialisasi Program Kerja Program Hibah Bina Desa

Penyuluhan tentang teknologi bioflok dengan pemanfaatan air irigasi dalam pengembangan akuakultur sebagai wisata edukasi dan sistem koperasi.

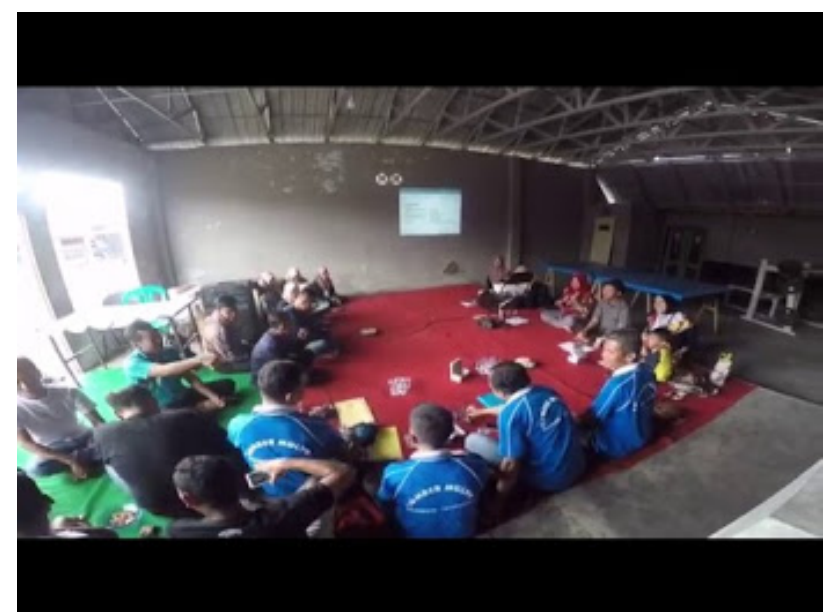

Gambar 2. Penyuluhan Kepada Kelompok Ikan Sumber Mulyo

Kegiatan Pelatihan Pembentukan Bioflok Pupuk Organik (sebagai starter awal) menyiapkan bahan dan cara berikut Bahan :

Tepung sagu $(C=49,84 \%) 2,480 \mathrm{~kg}$
Urea $0,3925 \mathrm{~kg}$

Garam non-iodium $5 \mathrm{sdm}$

Probiotik (Bacillus spp) $80 \mathrm{ml}$ (cair)

Air Secukupnya

Ragi tape 5 gram (direndam air hangat)

Adapun Cara Pembuatan : Semua bahan dicampur dan diaduk secara merata dalam bak. Kemudian. Tambahkan air secukupnya hingga adonan seperti pasta encer. Tunggu selama 3 hari, dan tiap 4-6 jam sekali diaduk. Tahap akhir Tebarkan $1 / 4$ adonan pada pagi hari dan dapat disusul setiap 3 hari

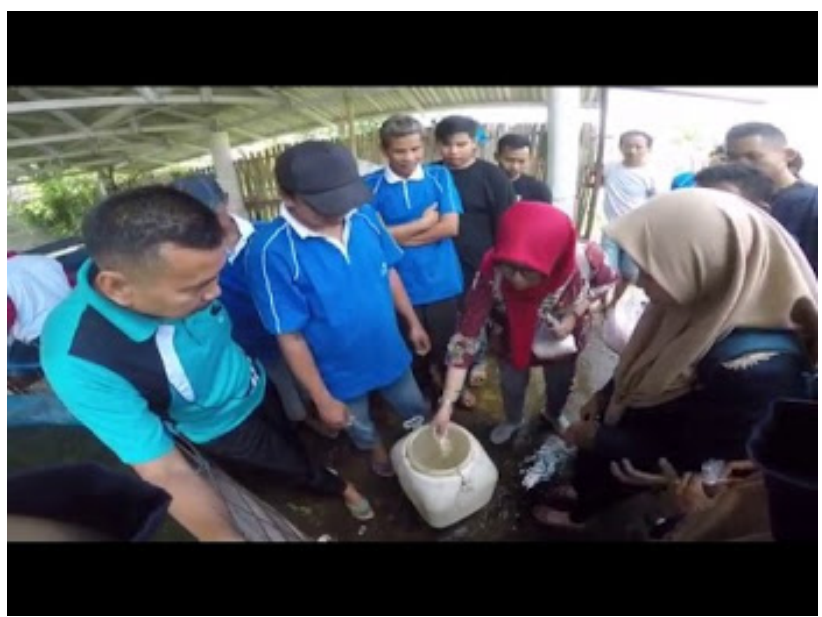

Gambar 3. Pelatihan Pembuatan Starter Awal

4.6. Strategi pembinaan khalayak sasaran

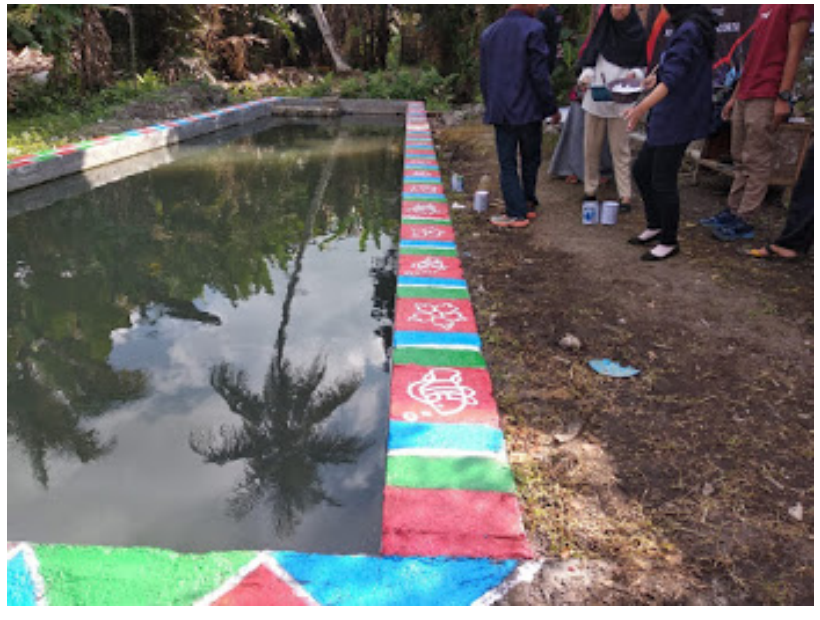

Gambar 4. Proses Pengecatan Kolam Budidaya Ikan Sebagai Wisata Edukasi

Melakukan pelatihan budidaya ikan yang di bina oleh dinas perikanan Banyuwangi, sosialisasi kegiatan program teknologi bioflok dengan pemanfaatan air irigasi dalam pengembangan akuakultur. Mendatangkan 
stakeholder yang ahli dibidangnya untuk meningkatkan produktivitas usaha kelompok ikan. Selain itu untuk menambah nilai jual tim pengabdi melakukan pengecatan kolam budidaya ikan seperti pada Gambar 4.

\subsection{Perintisan kemitraan}

Penjalinan kemitraan dengan balai pembibitan ikan, Dinas Perikanan Kabupaten Banyuwangi, karang taruna Sumbermulyo, ibuibu PKK dan kelompok pembudidaya ikan Sumbermulyo.

\subsection{Monitoring dan evaluasi berdasarkan indikator keberhasilan program}

Pada proses monitoring dilakukan pembuatan pembukuan dan melakukan audit setiap bulannya.

Metode pelaksanaan dalam program ini adalah membuat inovasi produk si perikanan budidaya yang berkelanjutan dengan berlandaskan pada adaptasi dan motivasi perubahan iklim. Cara seperti ini, bisa dipertimbangkan karena di masa mendatang perikanan budidaya diprediksi akan menjadi andalan dunia untuk pemenuhan kebutuhan pangan. Pengembangan teknologi bioflok yang memungkinkan peningkatan produktivitas tinggi, ramah lingkungan efisien dalam penggunaan lahan dan sumber daya air. Teknologi Bioflok di aplikasikan dalam sebuah tabung kolam bundar dan dapat dilihat pada

\section{Gambar 5.}

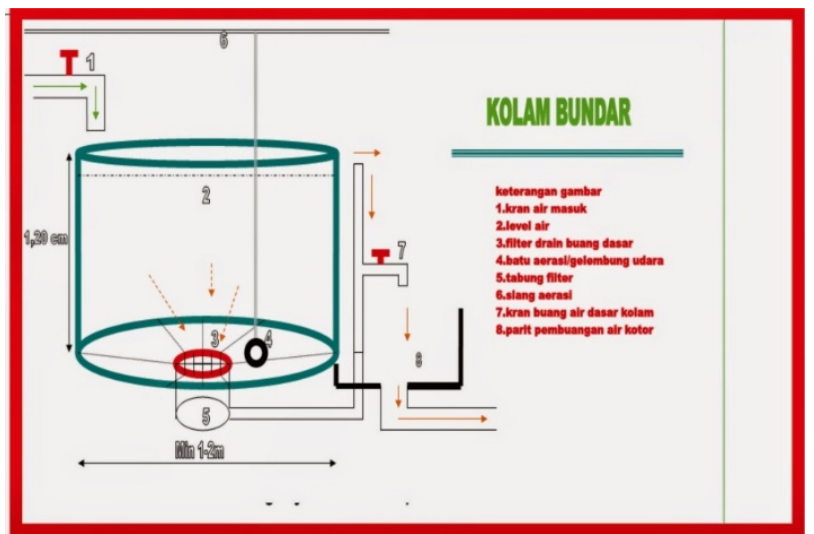

Gambar 5. Sketsa Teknologi Bioflok

Teknologi bioflok tersebut mengadopsi bentuk rekayasa lingkungan yang mengandalkan suplai oksigen dan pemanfaatan mikroorganisme, dan secara langsung dapat meningkatkan nilai kecernaan pakan. Kelebihan dari teknologi bioflok ini, bisa mengintegrasikan diri dengan sistem hidroponik, nilai survival rate/SR hingga lebih dari 90 persen dan tanpa pergantian air, nilai Feed Conversion Ratio (FCR) mencapai 1,03.

Secara terminologi bio-floc berasal dari dua suku kata yaitu bio yang berarti biologi atau hidup dan floc yang berarti gumpalan. Bio-Floc adalah flok atau gumpalan-gumpalan kecil yang tersusun dari sekumpulan mikroorganisme hidup yang melayang-layang di air.

Teknologi BIO-FLOC adalah teknologi yang memanfaatkan aktivitas mikroorganisme yang membentuk flok. Aplikasi BFT (Bio Floc Technology) banyak diaplikasikan di sistem pengolahan air limbah industri dan mulai diterapkan di sistem pengolahan air media akuakultur.

Biofloc sendiri tersusun dari beberapa komponen yaitu : exopolisakarida, bakteri pembentuk flok dan bakteri siklus fungsional. Exopolisakarida adalah senyawa polisakarida yang dihasilkan oleh bakteri pembentuk flok. Exopolisakarida ini bersifat seperti glue atau lem yang menjadi tempat penempelan bakteri menjadi satu kesatuan bioflok. Tidak semua bakteri mampu menghasilkan exopolisakarida ini, hanya bakteri tertentu saja yang mampu menghasilkan exopolisakarida ini. Bakteri penghasil exopolisakarida ini merupakan bakteri pembentuk inti flok, dan disebut sebagai Floc Forming Bacteria (bakteri pembentuk flok). Beberapa bakteri pembentuk flok yang sudah teruji diaplikasikan di lapangan adalah Achromobacter liquefaciens, Arthrobacter globiformis, Agrobacterium tumefaciens, Pseudomonas alcaligenes, Zoogloea ramigera, sistem bioflok dapat dilihat pada Gambar 6.

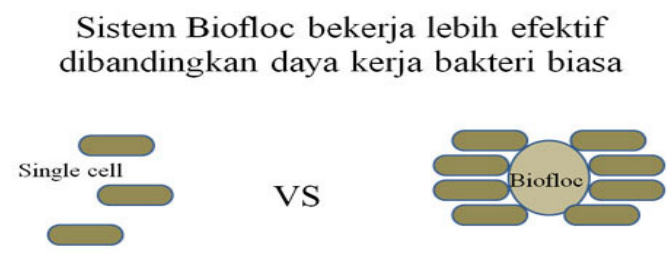

-Efek kerja bakteri lebih muncul

- Ketahanan sistem bakteri lebih stabil

-Perlawanan terhadap bakteri patogen lebih efektif

Gambar 6. Sistem Bioflok 
Bakteri lain dapat ikut membentuk bio-floc setelah exopolisakarida dibentuk oleh bakteri pembentuk floc sebagai inti flok-nya. Bakteri yang dapat ikut membentuk bio-floc misalnya Bacillus circulans, Bacillus coagulans, Bacillus licheniformis, Bacillus subtillis dll. Bakteri yang ikut membentuk flok ini mempunyai fungsi dalam siklus nutrisi di dalam sistem bioflok. Bakteri ini disebut sebagai bakteri siklus fungsional, misalnya Bacillus licheniformis yang berperan dalam siklus nitrogen. Tahapan pembentukan bakteri pada Bioflok dapat dilihat pada Gambar 7.

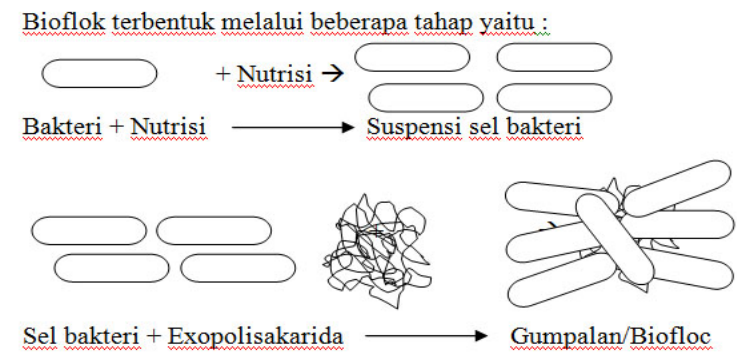

Gambar 7. Tahapan Terbentuknya Bioflok

Keunggulan sistem bioflok ini adalah dapat menghindari masuknya bibit penyakit dari luar, parameter air lebih stabil dan efek kerja bakteri lebih muncul. Sistem bioflok lebih stabil dibandingkan dengan sistem probiotik biasa dikarenakan bioflok merupakan bakteri yang tidak berdiri sendiri, melainkan berbentuk flok atau kumpulan beberapa bakteri pembentuk flok yang saling bersinergi. Sedangkan sistem probiotik biasa bakteri yang ada ditambak merupakan sel-sel bakteri yang berdiri sendiri secara terpisah di air, sehingga apabila ada gangguan lingkungan atau gangguan bakteri lain maka bakteri akan cepat kolaps. Aplikasi teknologi bioflok dapat meningkatkan pendapatan para kelompok budidaya ikan, sehingga dapat meningkatkan sarana prasarana akuakultur yang diperlukan dalam pengembangan budidaya perikanan darat. Cara pengukuran indikatornya dengan semakin meningkatnya produktivitas ikan, masa panen lebih cepat, dan mampu produksi pakan ikan secara mandiri. Potensi-potensi lokal yang ada di masyarakat untuk menerapkan inovasi ini antara lain wilayahnya sangat cocok untuk budidaya ikan air tawar, tersedianya air irigasi yang sangat melimpah yang sangat berpotensi untuk mengaliri kolam ikan, dan kolam - kolam ikan tersebut dapat di kembangkan menjadi wisata edukasi kampung ikan.

\section{Kesimpulan}

Pengaplikasian teknologi bioflok untuk pengembangan akuakultur dengan pemanfaatan air irigasi dapat mengurangi jumlah pakan yang digunakan pada saat budidaya, serta menjadikan desa Tulungrejo sebagai desa percontohan sebagai wisata edukasi kampung ikan dan terbentuknya koperasi ikan yang memudahkan kelompok ikan untuk memutar hasil panen. Kedepannya diharapkan akan keberlanjutannya program ini untuk mengoptimalkan desa Tulungrejo lebih baik lagi dalam segala hal.

\section{Ucapan Terima Kasih}

Kami mengucapkan terima kasih kepada Politeknik Negeri Banyuwangi yang telah memberikan dukungan pendanaan pada kegiatan Program Hibah Desa Binaan ini melalui Pusat Penelitian dan Pengabdian Kepada Masyarakat

\section{Daftar Pustaka}

[1] Avnimelech dan Ritvo. 2003. Shrimp and fish pond soil:processes and management. Jurnal Aquaculture, 220: 549-567. Diakses 2 September2019.http://ejournalbalitbang.kkp.go.id/in dex.php/jra/article/download/2380/1926

[2] Avnimelech. 2009. Biofloc Technology.World Aquaculture Society, Louisiana, USA, pp.182

[3] Faridah, Selvie Diana, Yuniati. 2019. Budidaya Ikan lele Dengan Metode Bioflok Pada peternak Ikan Lele Konvensional. Caradde: Jurnal pengabdian Kepada Masyarakat. Vol 1 (2) : $224-227$.

[4] Ilham Zulfahmi, Muhammad Syahimi, Muliari. 2018. Pengaruh Penambahan Bioflok Dengan Dosis Berbeda Terhadap Pertumbuhan Benih Udang Windu (Panaeus monodon FABRICIUS 1798). ALKAUNIYAH; Journal of Biology. Vol 11(1):1 - 8.

[5] Muhammad Wijaya, Rita Rostika, Yuli Andriani. 2016. Pengaruh pemberian $\mathrm{C} / \mathrm{N}$ Rasio Berbeda Terhadap Pembentukan Bioflok dan Pertumbuhan Ikan Lele Dumbo (Clarias gariepinus). Jurnal Perikanan Kelautan. Vol. VII (1):41-47.

[6] Mohammad Atmin.. 2019. Pemerintah Desa Tulungrejo Buku Profile Tahun 2019. Prodeskel.pmd.kemendagri.go.id. 
[7] Nasyir Husain, Berta Putri, Supono. 2014. Perbandingan Karbon Dan Nitrogen Pada Sistem Bioflok Terhadap Pertumbuhan Nila Merah. e-Jurnal Rekayasa Dan Teknologi Budidaya Perairan. Volume 3 (1): 334 -350.

[8] Purnomo, P.D. 2012. Pengaruh Penambahan Karbohidrat Pada Media Pemeliharaan Terhadap Produksi Budidaya Intensif Nila (Oreochromis niloticus). Fakultas perikanan dan Ilmu kelautan, Universitas Diponegoro, Journal of Aquaculture management and Technology: $161-179$. 